\title{
Sylwetka duchowa biskupa Karola Wojtyły - Jana Pawła II w osobistych notatkach
}

Zachowane notatki osobiste ${ }^{2}$ bpa Karola Wojtyły już w chwili śmierci wzbudziły duże zainteresowanie. W testamencie papież napisał, że powinien je spalić ks. Stanisław Dziwisz, sekretarz osobisty i najbliższy współpracownik ojca świętego, który towarzyszył mu w ciągu prawie 40 lat jego posługi biskupiej w Krakowie i Piotrowej w Rzymie. Ze względu na szacunek dla autora dzisiejszy metropolita krakowski nie zniszczył ich, lecz przedstawił Kongregacji do Spraw Świętych badającej życie ojca świętego w procesie beatyfikacyjnym. Już pobieżne przyjrzenie się notatkom potwierdziło, że ich autor miał bogate życie wewnętrzne obejmujące wszystkie wymiary jego działalności.

Notatki duchowe odsłaniają głębię życia z Bogiem Karola Wojtyły - biskupa pomocniczego, arcybiskupa krakowskiego, kardynała i papieża na przestrzeni kilkudziesięciu lat (1962-2003). Ukazują tajemnicę serca Piotra naszych czasów, który w trudnych czasach komunizmu był biskupem w Krakowie,

$1 \quad$ Ks. dr hab. Jan Machniak, prof. Uniwersytetu Papieskiego Jana Pawła II w Krakowie, kierownik Katedry Teologii Duchowości, dyrektor Instytutu Teologii Duchowości. Autor wielu książek o św. Faustynie, a także o życiu św. Józefa Bilczewskiego czy św. Józefa Sebastiana Pelczara.

Karol Wojtyła - Jan Paweł II, ,Jestem bardzo w rękach Bożych”. Notatki osobiste. 1962-2003, Kraków 2014 [dalej: Notatki osobiste]; por. Jan XXIII, Dziennik duszy, przekł. J. Ledóchowska, Kraków 2014. 
a potem przez prawie 27 lat prowadził łódź Piotrową po wzburzonych falach XX i XXI wieku. Zapiski duchowe zawierają refleksje, jakie papież notował, analizując swoje przeżycia wewnętrzne, postanowienia, modlitwy, rozmyślania i uwagi dotyczące postępu duchowego. Wyrażają przede wszystkim osobistą relację ich autora z Bogiem, który był w centrum jego życia wewnętrznego. Można je porównać z Dziennikiem duszy Jana XXIII, ze świadomością różnicy między osobowością jednego i drugiego papieża.

\section{Dwa zeszyty}

Notatki duchowe bpa Karola Wojtyły - Jana Pawła II zostały sporządzone w dwóch zeszytach: w kalendarzu „Agenda 1962” i „Agenda 1985”. Oba kalendarze zostały wydane we Włoszech przez archidiecezję mediolańską. Pierwszy kalendarz bp Wojtyła otrzymał prawdopodobnie od kogoś znajomego. Wprowadził w nim własną numerację stron od 1 do 220. Notatki jednak nie są prowadzone chronologicznie: pierwsze informacje dotyczą rekolekcji, jakie przeżywał abp Karol Wojtyła od 1 do 4 września 1971 roku razem z episkopatem Polski na Jasnej Górze. Dopiero na kolejnych stronach pojawiają się zapiski wcześniejsze - z 8 sierpnia 1962 roku. Notatki kończą się uwagami na temat rekolekcji prowadzonych w Watykanie przez kard. Aleksandra do Nascimento od 11 do 17 marca 1984 roku.

Drugi zeszyt należał pierwotnie do sekretarza papieskiego, ks. prałata Emeryka Kabongo, o czym świadczy zamazany napis na pierwszej stronie i odciśnięta sucha pieczęć. W środku pieczęci skrót „EK”, na okręgu „Library of Emery Kabongo" (Biblioteka Emeryka Kabongo). Notatki ojca świętego Jana Pawła II rozpoczynają się na stronie z datą 5 stycznia i obejmują kolejne 315 stron, z których nie wszystkie zostały zapisane.

Notatki bpa Karola Wojtyły, metropolity krakowskiego, kardynała, następnie papieża Jana Pawła II zawierają refleksje z dni skupienia i rekolekcji prywatnych (odprawianych w Kalwarii Zebrzydowskiej, u benedyktynów w Tyńcu, u Sióstr Urszulanek Serca Jezusa Konającego w Jaszczurówce w Zakopanem, u paulinów na Bachledówce, u albertynek w Krakowie na Prądniku, w tzw. „chatce” - w budynku stojącym w ogrodzie przy domu generalnym sióstr albertynek na ul. Woronicza 10, u albertynek w Rząsce) 
oraz z rekolekcji rocznych przeżywanych wspólnie z episkopatem Polski na Jasnej Górze. Już w pierwszym zeszycie pojawiają się zapiski z konklawe z październiku 1978 roku i z pierwszych lat pontyfikatu do 1984 roku$^{3}$.

Pierwszy zeszyt obejmuje więc lata posługi Karola Wojtyły jako biskupa pomocniczego i metropolity krakowskiego, począwszy od rekolekcji 8 sierpnia 1962 roku. Zapiski można uporządkować w następującej kolejności:

- rekolekcje przed wyjazdem do Rzymu: 8 lipca 1962 - s. 144 [s. 17 w książce];

- dzień rekolekcji (dies recollectionis) po przybyciu do Rzymu na I sesję soboru watykańskiego II: październik 1962 - s. 149 [s. 20-22];

- rekolekcje u sióstr felicjanek w Rzymie z okazji rocznicy święceń kapłańskich: 31 października - 4 listopada 1962 - s. 160 [s. 24-31];

- rekolekcje w Tyńcu: 19-23 sierpnia 1963 - s. 122 [s. 34-43];

- rekolekcje przed ingresem do katedry wawelskiej: 5-7 marca 1964 - s. 35 [s. 44-46];

- rekolekcje na Jasnej Górze, prowadzone przez bpa Józefa Kowalskiego: 31 sierpnia - 3 września 1964 - s. 131 [s. 47-55];

- rekolekcje w Tyńcu: 18-20 sierpnia 1965 - s. 137 [s. 56];

- rekolekcje w Kalwarii Zebrzydowskiej: 31 października - 1 listopada 1966 - s. 159 [s. 66-63];

- rekolekcje u albertynek: 19-21 grudnia 1966 - s. 186 [s. 67-73];

- rekolekcje w Tyńcu: 12-14 września 1968 - s. 145 [s. 76-83];

- rekolekcje w Bachledówce: 10-12 sierpnia 1969 - s. 153 [s. 84-94];

- rekolekcje w Tyńcu: 4-7 listopada 1970 - s. 168 [s. 95-102];

- rekolekcje episkopatu Polski na Jasnej Górze, prowadzone przez bpa Lecha Kaczmarka: 1-4 września 1971- s. 1 [s. 104-112];

- rekolekcje w Kalwarii Zebrzydowskiej: 5-6 lipca 1973 - s. 11 [s. 115-116];

- rekolekcje na Bachledówce: 9-12 sierpnia 1973 - s. 13 [s. 117-120];

- rekolekcje episkopatu w Gnieźnie:3-6 września 1974 - s. 27 [s. 133-146];

- rekolekcje na Bachledówce: 4-8 lipca 1975- s. 37 [s. 147-156];

- rekolekcje w Jaszczurówce, Zakopane: 21-25 września 1976 - s. 46 [s. 157-169];

3 A. Boniecki, Kalendarium życia Karola Wojtyły, Kraków 1983, s. 26, 28, 38, 100, 103, 107, $121,130,143-144,147,151,158-159,165,193-194,199,239,291,293,308,310,313,323,333$, $367-$ 368, 439-440 487-491, 524-525, 561-562, 572-575. 
- rekolekcje w Kalwarii Zebrzydowskiej:5-9 lipca 1977 - s.59[s. 170-181];

- rekolekcje w Kalwarii Zebrzydowskiej: 26-29 czerwca 1978-s. 71 [s. 183-196].

- Rekolekcje w czasie posługi na Stolicy Piotrowej w kaplicy św. Matyldy:

- 4-10 marca 1979, o. Faustino Osanna OFM - s. 85 [s. 198-213];

- 24 lutego - 1 marca 1980, abp Moreira Neves OP - s. 95 [s. 215-237];

- 8-14 marca 1981, bp Jerzy Ablewicz - s. 108 [s. 238-262];

- 28 lutego - 6 marca 1982, o. Stanislas Lyonnet SJ - s. 179-185, 192196 [s. 263-282];

- 20-26 lutego 1983, kard. Joseph Ratzinger - s. 197 [s. 283-302];

- 11-17 marca 1984, kard. Alexandre do Nascimento - s. 210 [s. 303-319].

(Zeszyt drugi)

- 24 lutego - 2 marca 1985, abp Achille Glorieux - s. 5-19 [s. 321-335];

- 16-22 lutego 1986, ks. Egidio Viganò SDB - s. 21 [s. 337-357];

- 8-14 marca 1987, o. Peter-Hans Kolvenbach SJ - s. 42 [s. 359-380];

- 21-27 lutego 1988, abp James A. Hickey - s. 63 [s. 381-399];

- 12-18 lutego 1989, kard. Giacomo Biffi - s. 79 [s. 400-420];

- 4-10 marca 1990, o. George Marie Martin Cottier OP - s. 98 [s. 421-439];

- 17-23 lutego 1991, abp Ersilio Tonini - s. 116 [s. 440-456];

- 8-14 marca 1992, kard. Ugo Poletti - s. 130 [s. 457-476];

- 28 lutego - 6 marca 1993, abp Jorge Arturo Medina Estévez - s. 150 [s. 477-495];

- 20-27 lutego 1994, abp Giovanni Saldarini - s. 168 [s. 497-517];

- 5-11 marca 1995, o. Tomáš Špidlik SJ - s. 186 [s. 518-525];

- 25 lutego - 3 marca 1996, abp Christoph Schönborn - s. 196 [s. 526-548];

- 16-22 lutego 1997, kard. Roger Etchegaray - s. 219 [s. 549-565];

- 1-7 marca 1998, kard. Jan Chryzostom Korec SJ - s. 239 [s. 567-585];

- 21-27 lutego 1999, bp André-Mutien Léonard - s. 258 [s. 586-594];

- 12-18 marca 2000, kard. François Xavier Nguyen Van Thuan - s. 270 [s. 595-610];

- 4-10 marca 2001, kard. Francis Eugene George OMI - s. 286 [s. 611-621];

- 17-23 lutego 2002, kard. Claudio Hummes OFM - s. 298 [s. 622-627];

- 9-15 marca 2003, bp Angelo Comastri - s. 304 [s. 629-634]. 
Notatki z rekolekcji zarówno w pierwszym, jak i drugim zeszycie były prowadzone w języku polskim. Często jednak ich autor wprowadzał wyrażenia w języku łacińskim i włoskim, szczególnie w czasie rekolekcji watykańskich. Rekolekcje w Watykanie dla ojca świętego i kurii rzymskiej były prowadzone w języku włoskim.

\section{Porządek dnia rekolekcyjnego}

Ważne miejsce w rekolekcjach i dniach skupienia przeżywanych przez kard. Karola Wojtyłę, potem papieża Jana Pawła II zajmował plan dnia. Schemat rekolekcji wypracowany w Krakowie, kiedy bp Karol Wojtyła rozpoczynał swoją posługę, obejmował trzy konferencje, lectio spiritualis - czytanie duchowne, corona rosarii - różaniec, via crucis - drogę krzyżową, adoratio - adorację, matutinum - jutrznię, lectio-czytanie, sacrum lub officium Echaristicum - mszę świętą, vesperes - nieszpory, adoratio Sanctissimi Sacramenti - adorację Najświętszego Sakramentu, completorium - kompletę ${ }^{4}$.

Arcybiskup Karol Wojtyła przeżywał rekolekcje według metody ignacjańskiej ${ }^{5}$, której pozostał wierny do końca życia. Metody tej nauczył się w seminarium duchownym pod czujnym okiem swojego ojca duchownego, ks. Stanisława Smoleńskiego, późniejszego biskupa pomocniczego archidiecezji krakowskiej. Metoda ta wymagała zawsze dokładnego określenia tematu rozważań i lektury duchownej. W czasie posługi biskupiej w Krakowie dni skupienia i rekolekcje prowadził sam abp Karol Wojtyła, konsultując sprawy duchowe z kierownikiem duchowym - bpem Stanisławem Smoleńskim lub ks. Aleksandrem Fedorowiczem, który w latach sześćdziesiątych XX wieku był ojcem duchownym Lwowskiego Seminarium Duchownego w Kalwarii Zebrzydowskiej, a potem opiekunem duchowym w Laskach pod Warszawą. Przyjeżdżał on również do Rzymu i służył radą ojcu świętemu.

Metoda rozważania pozwalała bpowi Karolowi Wojtyle uporządkować cały dzień skupienia czy rekolekcji według charakterystycznego planu. Rytm dnia rekolekcyjnego wyznaczał brewiarz, odmawiany najpierw we-

Por. S. Dziwisz, Świadectwo, Warszawa 2007, s. 77.

Por. św. Ignacy Loyola, Ćwiczenia duchowne, przekł. J. Ożóg, Kraków 1999. 
dług metody przedsoborowej z matutinum (jutrznia), laudes (modlitwa pochwalna), tercją (trzecia), sekstą (szósta) i noną (dziewiąta), completorium (kompleta). Rekolekcje w Tyńcu odprawiane w dniach od 19 do 23 sierpnia 1963 roku rozpoczął abp Karol Wojtyła wieczorem kompletą, adoracją i medytacją. Kontynuował następnego dnia, zachowując następujący porządek:

- laudes prima - laudesy pierwsze;

- meditatio ante sacrum - rozmyślanie przed mszą świętą;

- sacrum - msza święta;

- gratiarum actio - dziękczynienie;

- lectio S. Scripturae - czytanie Pisma Świętego;

- meditatio - medytacja;

- via crucis - droga krzyżowa;

- vesperes - nieszpory;

- adoratio - adoracja;

- rosarium - różaniec;

- lectio spiritualis - czytanie duchowne;

- meditatio - medytacja;

- matutinum anticipatum - jutrznia antycypowana;

- lectio S. Scripturae - czytanie duchowne z Pisma Świętego;

- rosarium - różaniec;

- colloquium cump. Augustinus - rozmowa z o. Augustynem [Hadamem OFM]; cum fr. Michael - z br. Michałem;

- completa - kompleta;

- hora sancta - godzina święta;

- lectio - czytanie duchowne.

Biskup Karol Wojtyła pozostał wierny takiemu porządkowi dni skupienia i rekolekcji przez całe życie, czego dowodem są późniejsze notatki, szczególnie z czasów, kiedy był papieżem. W 1981 roku rekolekcje wielkopostne (8-14 marca) w Watykanie prowadziłbp Jerzy Ablewicz z Tarnowa ${ }^{6}$. Tematem rozważań były słowa Pana Jezusa: „Będziecie moimi świadkami” (Dz 1,8). Rekolekcje rozpoczęły się nieszporami (Vesp[eres]) 8 marca 1981 roku o godz. 18.00. Trzeci dzień rekolekcji (10 marca 1981) miał typowy układ:

$6 \quad$ J. Ablewicz, Będziecie moimi świadkami: rekolekcje watykańskie, Paryż 1983. 
1. act[us] int[encionis] oraz medit[atio] mat[utina] - obudzenie intencji i medytacja poranna;

2. sacrum - msza święta;

3. laudes - jutrznia;

4. konferencja VI - „Świadectwo słowa Bożego”;

4a. refleksja;

5. tertio - modlitwa w ciągu dnia;

6. konferencja VII - „Świadectwo dawane Ojcu”;

6a. medit[atio] Refl[exiva];

7. seksta, nona - modlitwy w ciągu dnia;

7a. via crucis („Miserere”) - droga krzyżowa i psalm „Zmiłuj się, Boże”;

8. ador[atio] Ss-mi - adoracja Najświętszego Sakramentu;

8a. lectura sanct. et aliae - czytanie duchowne;

9. cor[ona] ros[arii] III, I - różaniec;

10. vesp[eres] - nieszpory;

11. konf[erencja] VIII - „Świadczenie o zmartwychwstaniu Chrystusa”;

11a. refl[eksja];

12. matut [inum] anticip[atum] - matutinum antycypowane;

13. konf[erencja] IX - „Maria: testimonianza della cultura” (Maryja: świadek kultury);

14. cor[ona] Ros[arii] II - część różańca;

15. devotio Eucharistica (adoratio) - nabożeństwo eucharystyczne;

16. meditatio conclusiva - medytacja podsumowująca;

17. compl[eta] - kompleta.

Rekolekcje zakończyły się śpiewem pieśni Maryi Magnificat.

\section{Treść notatek}

Notatki duchowe sporządzane w czasie rekolekcji odzwierciedlają stan ducha bpa Karola Wojtyły, potem papieża Jana Pawła II. Pokazują jego wrażliwość na problemy, którymi żył Kościół w Polsce i Kościół powszechny. Ich autor starał się sam przygotować temat dnia skupienia lub rekolekcji odprawianych prywatnie. W czasie rekolekcji przeżywanych z episkopatem Polski korzystał z myśli rekolekcjonisty, by snuć własną refleksję na temat 
relacji z Bogiem i sposobu wypełniania obowiązków biskupa, które stanowiły treść jego życia.

Pierwszy zeszyt rozpoczyna się od notatek z rekolekcji episkopatu Polski, które odbywały się na Jasnej Górze w dniach od 1 do 4 września 1971 roku. Rekolekcje prowadził bp Lech Kaczmarek. Ostatnie notatki w tym zeszycie pochodzą z rekolekcji watykańskich 11-14 marca 1984 roku. Wewnątrz notatnika znajdujemy jednak zapiski z lat wcześniejszych, począwszy od 1962 roku, które przeplatają się refleksjami z rekolekcjami przeżywanymi później. Z takiego układu wynika, że autor wpisywał uwagi według własnej kolejności, powracał do przeżyć sprzed lat i dokonywał konfrontacji osobistych przeżyć duchowych.

Autor notatek jawi się jako osoba niezwykle systematyczna i bardzo dobrze zorganizowana oraz skupiona na problematyce duchowej. Nie rozprasza się na opisywaniu stanów emocjonalnych czy szczegółów dotyczących bieżących wydarzeń lub osób w nich uczestniczących. Całą uwagę koncentruje na tym, na ile odzwierciedla w swoim życiu Chrystusa - Najwyższego Kapłana. Notatki rozpoczyna zwykle od dedykacji „AMDG” - „Ad maiorem Dei gloriam” - „Na większą chwałę Bożą” oraz od znaku „J+M” - Jan - Krzyż Chrystusa - Maryja, co jest nawiązaniem do sceny ukrzyżowania, opisanej przez św. Jana Ewangelistę $(\mathrm{J} 19,26)$ i podkreśla ich duchowy charakter. Na końcu papież pisał zwykle skrót: AMDG/UIOGD („Ad maiorem Dei gloriam / Ut in omnibus glorificetur Deus” - „Niech we wszystkim będzie Bóg uwielbiony").

Rysem charakterystycznym notatek jest ich chrystocentryzm. Biskup Karol Wojtyła odnosił wszystkie swoje przeżycia do Chrystusa - Najwyższego Kapłana. Z Nim starał się nawiązać osobisty kontakt przez regularną modlitwę, rozważanie słowa Bożego i posługę pasterską. Do Chrystusa odnosił wszystkie swoje osobiste sprawy oraz problemy, jakimi żył jako biskup diecezji, kardynał i papież.

W centrum każdego dnia autora notatek była msza święta. Wieczorem, przed udaniem się na odpoczynek nocny, przygotowywał się do mszy świętej. Rano prowadził medytację poranną, po mszy świętej i w ciągu dnia dziękczynienie, wieczorem godzinę świętą przed Najświętszym Sakramentem. Eucharystia była dla Karola Wojtyły - Jana Pawła II miejscem doświadczania ofiary Chrystusa i jednocześnie składania swojego życia Bogu w ofierze. Była 
stylem życia polegającym na traceniu siebie, tak jak Chrystus wyniszczył samego siebie na krzyżu. Przez codzienne sprawowanie mszy świętej jednoczył się z jedyną ofiarą Chrystusa i wchodził w osobistą relację z Bogiem w Trójcy jedynym: Ojcem, Synem i Duchem Świętym.

Cechą charakterystyczną notatek bpa Karola Wojtyły - Jana Pawła II jest rys maryjny, rozwijany wokół teologii i duchowości traktatu św. Ludwika Marii Grignona de Monforta O doskonałym nabożeństwie do Najświętszej Maryi Panny. Maryja jawi się w modlitwach i rozmyślaniach ks. Wojtyły jako ta, która w doskonały sposób przyjęła i wypełniła wolę Bożą. Autor notatek podkreśla jej wielkość, która wyraziła się w niezwykłym obdarowaniu łaską Bożą ze względu na wybranie jej na Matkę Słowa Wcielonego. Jednocześnie Maryja była dla ojca świętego osobą dojrzałą w wierze, która podjęła decyzję: „fiat” - „niech mi się stanie według słowa twego” - stając się uczestniczką Bożego planu zbawienia.

\section{Dynamika ćwiczeń duchownych}

W notatkach z 8 sierpnia 1962 roku bp Karol Wojtyła zanotował główne tematy pracy wewnętrznej, które omawiał z „ojcem” - kierownikiem duchowym, ks. Aleksandrem Fedorowiczem7 ${ }^{7}$ 1. śmierć, 2. władza, 3. twórczość, 4. osoby. Rozważane problemy dotykały istoty życia wewnętrznego: relacji z Bogiem i z bliźnimi. Pod datą 2 września tego samego roku znajduje się krótka notatka dotycząca pracy nad sobą według powyższych tematów oraz nowego problemu - wydobywania przeżyć i przemyśleń z przeszłości. Bp Karol Wojtyła odkrył nowe doświadczenie obecności Maryi w swoim życiu w duchu maksymy, którą wziął od św. Ludwika Marii Grignona de Montforta ${ }^{8}$ : „Totus Tuus - cały twój”.

Notatki są świadectwem udziału bpa Karola Wojtyły w soborze watykańskim II (1962-65) i jego wielkiej fascynacji tajemnicą Kościoła - rzeczywisto-

\footnotetext{
Jan Paweł II, Dar i Tajemnica, Kraków 1996, s. 38.

Św. Ludwik Maria Grignon de Montfort, Traktat o prawdziwym nabożeństwie do Najświętszej Maryi Panny, tłum. H. Brownsfordowa, Torun 1996; por. Jan Paweł II, Dar i Tajemnica, dz. cyt., s. $29,30$.
} 
ści łączącej różne ludy i narody. Po przybyciu na I sesję soboru watykańskiego II (9 października 1962) bp Karol Wojtyła przeżył dzień skupienia. Rano celebrował mszę świętą oraz odmówił brewiarz. Zapisał w swoim dzienniku, że uczestniczył w capella papalis z okazji 4. rocznicy śmierci papieża Piusa XII. Uderzyło go, że wśród tak wielu obecnych ojców soborowych panuje ,jeden duch", a jedność w wielości wyraża się w zjednoczeniu z ojcem świętym i w jedności wewnętrznej, moralnej, w ,jedności życiowej”. Druga myśl, która towarzyszyła bpowi Wojtyle, dotyczyła kapłaństwa i biskupstwa jako całkowitego zjednoczenia z Chrystusem i działania w Chrystusie. Podczas adoracji rozważał tajemnicę obecności Chrystusa w Kościele i Kościoła w Chrystusie. Dzień skupienia zakończył refleksją nad tym, czym w przypadku Kościoła jest teoria, a czym praktyka. Kilka dni później (14 października 1962) w medytacji poświęconej spotkaniu w człowieku ducha ludzkiego z Duchem Bożym bp Wojtyła zwrócił uwagę na problem dostosowania ducha ludzkiego do Ducha Bożego i współpracy w tym dziele z Duchem Świętym.

Rozważając temat najświętszego człowieczeństwa Chrystusowego w czasie rekolekcji episkopatu Polski (31 sierpnia - 3 września 1964), pytał siebie o codzienną adorację Najświętszego Sakramentu, przypominając sobie o konieczności częstego spotykania się z Chrystusem. Zatrzymał się nad problemem wiary rozumianej jako przyjęcie prawdy objawionej o Bogu, podkreślając jej personalistyczny charakter (18-20 sierpnia 1965). W swoich notatkach z dnia skupienia w Kalwarii Zebrzydowskiej (9-10 sierpnia 1968) pytał o realizację postanowień Soboru Watykańskiego II w archidiecezji krakowskiej i w Polsce. Powracał do spraw nawiedzenia obrazu Matki Bożej Częstochowskiej w dekanacie myślenickim i w dekanacie bolechowickim (Zielonki, 11 września 1968). Przypominał sobie o potrzebie przestudiowania notatek z poprzednich rekolekcji oraz sformułowania tematyki na następne rekolekcje.

Arcybiskup Karol Wojtyła starał się żyć konsekracją biskupią, dlatego w 10. rocznicę swoich święceń biskupich odprawił w Tyńcu rekolekcje na temat „zjednoczenia i odrzucenia” (12-14 września 1968). Rozważania rekolekcyjne poświęcił 10-leciu sakry biskupiej (1958). Zastanawiał się nad tym, co nieprzemijalne, duchowe. Tematyka posługi biskupiej w życiu abpa Karola Wojtyły powróciła w czasie rekolekcji episkopatu Polski, które odbywały się na Jasnej Górze od 1 do 4 września 1971 roku. Prowadził je bp Lech 
Kaczmarek, który rozwijał problemy szczegółowe: biskup obrazem Ojca, stróż wiary, mąż przepowiadania, liturg. Obok streszczeń konferencji abp Wojtyła notował własne uwagi, refleksje na temat swojego życia wewnętrznego oraz postanowienia pracy nad sobą. W ostatnim dniu - 4 września 1971 roku - zapisał osobistą uwagę, która odsłania głębię jego zjednoczenia z Bogiem:

W tym ostatnim dniu towarzyszyła mi szczególna świadomość Boga w Jego osobowej transcendencji względem dzieła stworzonego: świadomość Stwórcy i Ojca, który jest jednym Bogiem z Synem i Duchem Świętym. Równocześnie zaś świadomość niezwykłej immanencji tego Boga w świecie, przede wszystkim w boskości mocą Odkupienia dokonanego przez Syna, skąd płynie uświęcenie w Duchu Świętym. Świadomość Boga, który trzyma świat i przenika świat. Maryja jest w szczególny sposób obecna w tej tajemnicy, szczególnie blisko zespolona z Odkupieniem i uświęceniem, a przez to samo z Kościołem.

Rekolekcje zakończył aktem oddania siebie Matce Kościoła.

Kolejne notatki podkreślają dynamikę życia duchowego kard. Karola Wojtyły, wyrażającą się w refleksji nad przeżywaniem rekolekcji i dni skupienia (5-6 sierpnia 1973). Autor nawiązywał do zeszłorocznych rekolekcji i podjętych wówczas postanowień. Rozważał sprawę kapłaństwa i ofiary, próbując dociec, jak są one wpisane w istotę stworzenia świata i człowieka. W drugim dniu skupienia obchodził dróżki Pana Jezusa, stając nieustannie przed Zbawicielem i pytając o swoją wierność jako kapłana i pasterza.

W tym samym roku w dniach od 9 do 12 sierpnia abp Karol Wojtyła odprawiał w Zakopanem na Bachledówce rekolekcje poświęcone Trójcy Świętej. Podjął problem katolickiego wychowania młodzieży oraz temat „pojednania” zaproponowany przez papieża Pawła VI jako temat Roku Świętego. W czasie rekolekcji czytał książkę duchowną Le Mystère du Père o. Marie-Josepha Le Guillou', która była podstawą do rozmyślania podczas kolejnych „medytacji”. Zakończył dziękczynieniem Bogu za Maryję: „De Maria numquam satis” („O Maryi nigdy dosyć”). Lektura duchowna była inspiracją do rozważania wielkich tematów teologicznych i pomagała kard. Wojtyle wychodzić poza subiektywne odczucia. Problem tajemnicy Boga w Trójcy Świętej powrócił w czasie dnia skupienia (17-18 listopada 1973), a potem w rekolekcjach episkopatu Polski w Gnieźnie (3-7 września 1974), prowadzonych przez bpa Jerzego

9 M. J. Le Guillou, Le Mystère du Père. Foi des Apôtres, Paris 1973. 
Ablewicza na temat „W Chrystusie Bóg pojednał świat z sobą. W Chrystusie pojednajcie się z Bogiem”. Kard. Wojtyła sporządził obszerne notatki z rekolekcji, koncentrując się na tożsamości biskupa - tego, który jest znakiem Chrystusa głoszącego chwałę Ojca. Podkreślił, że chwała biskupa łączy się z krzyżem Chrystusa. Rekolekcje stały się dla abpa Karola Wojtyły okazją do zbadania (scrutinium) jego posługi biskupiej w archidiecezji krakowskiej ${ }^{10}$.

Temat kapłaństwa i posługi biskupiej podjął kard. Karol Wojtyła podczas rekolekcji u sióstr urszulanek w Zakopanem w Jaszczurówce (21-25 września 1976), rozważając temat „Sacerdos-Propheta-Rex” (Kapłan-Prorok-Król). Do problematyki kapłańskiej powrócił ponownie w czasie rekolekcji w Kalwarii Zebrzydowskiej (26-29 czerwca 1978), rozważając temat „Martyria-diakoniakoinonia" (Męczeństwo-służba-wspólnota) ${ }^{11}$. Na tych rekolekcjach kończą się notatki kard. Karola Wojtyły. Następne dotyczą już konklawe w Rzymie.

Pod datą 13 października 1978 roku kard. Karol Wojtyła zanotował, że jego „drogi przyjaciel” bp Andrzej Deskur doznał wylewu krwi do mózgu i paraliżu. Odwiedził go w szpitalu 14 października 1978 roku przed południem. Chorobę bpa Deskura odczytał jako znak od Boga: „Wszystko zostało wpisane poprzez jego cierpienie w tajemnicę Krzyża i Odkupienia dokonanego przez Chrystusa". Po południu rozpoczęło się konklawe, które trwało do 16 października. Następnego dnia po wyborze papież Jan Paweł II odwiedził ponownie swojego przyjaciela w szpitalu.

\section{Wierność do końca}

Do notatek duchowych powrócił Jan Paweł II w czasie rekolekcji watykańskich w dniach 4-10 marca 1979 roku. Pozostał wierny zasadzie prowadzenia dziennika duszy, zapisując z rekolekcji te sprawy, które najbardziej go dotyczyły, odnosząc je do swojego życia duchowego. Zapiski duchowe Jana Pawła II stanowią niezwykle cenne informacje o jego życiu wewnętrznym w czasach, kiedy kierował łodzią Piotrową. W zasadniczej treści są one

10 Por. W. Granat, Ku człowiekowi i Bogu w Chrystusie. Zarys dogmatyki katolickiej, t. 2, Lublin 1974.

11 Por. F. Blachnicki, Międzynarodowa Diakonia Ewangelizacji Światło-Życie, Carlsberg 1983. 
kontynuacją wcześniejszych notatek. Ich autor pozostał wierny planowi dnia, regularnej modlitwie brewiarzowej, modlitwie różańcowej i nabożeństwu drogi krzyżowej. Codziennie odprawiał nabożeństwo do Najświętszego Sakramentu połączone z adoracją.

Pierwsze rekolekcje w Watykanie zaczęły się nieszporami i konferencją 4 marca 1979 roku o godz. 18.30. Prowadził je franciszkanin o. Faustyn Ossanna. W pierwszej konferencji wprowadził w temat ćwiczeń rekolekcyjnych: „Otworzyć się dla Chrystusa”. Ojciec święty Jan Paweł II uczestniczył w pierwszych rekolekcjach wielkopostnych w kaplicy św. Matyldy. Porządek dnia był podobny do porząadku rekolekcji, które Jan Paweł II odprawiał jako arcybiskup krakowski. Obejmował on: matutinum, medytację, mszę świętą, laudesy, trzy konferencje w ciągu dnia, adorację Najświętszego Sakramentu, różaniec, drogę krzyżową, błogosławieństwo eucharystyczne, medytację wieczorną podsumowującą cały dzień rekolekcji, kompletę. Papież obrał sobie również lekturę - Poenitemini Pawła VI. Notował też treść konferencji, dodając uwagi dotyczące pracy nad sobą. Punktem wyjścia rekolekcji było stwierdzenie, że Chrystus żyje w nas, dlatego człowiek doświadcza Jego obecności i daje o Nim świadectwo. Z zamieszkania Chrystusa w człowieku wynika powołanie do świętości i konkretne działanie. On jest obecny w Kościele w sakramentach, w słowie Bożym. Chrześcijanin powinien ukazywać światu prawdziwe oblicze Chrystusa.

Kolejne rekolekcje wielkopostne prowadził abp Lucas Moreira Neves OP w dniach od 24 lutego do 1 marca 1980 roku, poświęcając je tematowi kapłaństwa, niezwykle ważnemu dla Kościoła, jak to zauważył papież Jan Paweł II. Rekolekcjonista rozważał temat kapłaństwa ministerialnego od strony sakramentalnej, jako udział w kapłaństwie Chrystusa. Celem życia kapłana jest chwała Boża, która wyraża się w liturgii, głoszeniu słowa Bożego i świadectwie życia. W czasie rekolekcji papież oprócz zwykłych ćwiczeń modlitewnych odmawiał Litanię do wszystkich świętych, litanię loretańską i Litanię do św. Józefa. Notatki rekolekcyjne zakończył skrótem AMDG i UIOGD.

W 1981 roku rekolekcje wielkopostne w Watykanie (8-14 marca) prowadził bp Jerzy Ablewicz. Temat - „Będziecie mi świadkami”. Rekolekcjonista rozważał pojęcie „świadek” (człowiek, który naśladuje Chrystusa, odtwarza w sobie rysy Zbawiciela). Podkreślał różne rodzaje świadectwa: świadectwo Kościoła, świadectwo modlitwy, sumienia, świadectwo kluczy, Maryja jako szczególny świadek zbawienia. Na s. 179-185, 192-196 zamieszczone są no- 
tatki z rekolekcji watykańskich w dniach 28 lutego - 6 marca 1982 roku, które prowadził o. Stanislas Lyonnet SJ. Tematem była obecność Boga w świecie i w człowieku. W 1983 roku rekolekcje w Watykanie prowadził kard. Joseph Ratzinger (s. 197). Rozważał scenę kuszenia na pustyni Pana Jezusa, który wszedł w historię swojego ludu i doświadczył jego słabości: głodu i pokus. Zanotowane uwagi z rekolekcji kard. do Nascimento 1984 są wezwaniem do szukania Boga.

1. Vesp.[eres]

2. Veni Crator

3. Konf.[erencja] Medit.[atio] (I)

Tworzymy wspólnotę rekolekcyjną. W centrum: Chrystus. Duch Św., który mówi „wewnątrz”.

Znajdujemy się w pośrodku Kościoła: w Rzymie - i w świecie. Kościół przygotowuje się do Paschy.

Wielki Post jest wezwaniem!

Temat: Symbol wiary.

W jedności z Matką Kościoła, z Lourdes: słowa do św. Bernadetty:

Święta Maryo Matko Boża, módl się za mną biednym grzesznikiem.

4. Ador.[atio] Euch.[aristica]

5. Cor.[ona] Ros.[arii] (III) Lit.[ania] SS. Cordis / BMV / S. Jos.

6. Compl.[eta]

/Lektury/

Następny dzień miał 20 punktów programu:

1. Int.[roductio]

2. Medit.[atio] / "Ja jestem pośrodku nich"/

3. Sacrum / grat.[iarum] actio

Orat.[io] cons.

Act. Mar. / SS. Spir.

Lit. za Ojczyznę

4. Laudes

5. Conf. Medit. (II)

/Credo/: Tylko Bóg może mówić dobrze o Bogu [...]

Symbolus Apostolorum: struktura trynitarna - symbolus baptismalis [...] 
6. Tertia

7. Conf. Medit. (III)

Analiza sekularyzmu [...]

8. Medit. sintetica „Tylko Bóg może mówić w sposób właściwy o Bogu...”

9. Seksta, Nona

10. Via Crucis (Trinit.)

[O Duchu Św. - lectura et medit.]

11. Ador.[atio] SSmi.

12. Cor. Ros. (II, III)

13. Vesp.

14. Conf. Medit. (IV)[...]

Liturgia pełna czci i uwielbienia Majestatu Bożego ref./Credo Populi Dei/

15. Matut.[inum] anticipatum

16. Conf. Med. (V)

Credo... in Creatorem coeli et terrae

17. Cor.[ona] Ros. (I)

18. Ador. euch[aristica]

19. Medit. concl.[usiva] [o miłości Boga]

20. Compl.[etorium]

Porządek taki zachowywał sługa Boży w każdym dniu rekolekcji, notując słowa i myśli z konferencji, które go uderzyły. Sam dobierał lekturę duchowną, odprawiał adorację Najświętszego Sakramentu i godzinę świętą, odmawiał litanie: do Najświętszego Serca Jezusowego, do Matki Bożej Loretańskiej, do Imienia Jezus i do św. Józefa. Śpiewał Gorzkie żale i odprawiał drogę krzyżową oraz rozważał Mękę Pańską.

W ostatnich latach notatki z rekolekcji stawały się coraz bardziej skromne. Ojciec święty zapisywał temat rekolekcji i program dnia. Mniej jest uwag własnych. Widać, że pisanie sprawiało mu coraz większą trudność. Zmieniał się również charakter pisma, które stawało się mniej wyraźne.

W 2005 roku rekolekcje watykańskie (13-15 lutego) prowadził bp Renato Corti z Novary, który zgodnie ze zwyczajem wygłaszał nauki w kaplicy Redemptoris Mater. Temat rekolekcji brzmiał: „Kościół na służbie nowego i wiecznego przymierza" (La Chiesa a servizio della nuova ed eterna al- 
leanza). Ojciec święty Jan Paweł II uczestniczył w rekolekcjach, łącząc się z kaplicą drogą radiową. Słuchał wszystkich konferencji i odprawiał ćwiczenia duchowne, które zwykł był praktykować prywatnie w czasie rekolekcji. W ćwiczeniach towarzyszył mu jego osobisty sekretarz abp Stanisław Dziwisz i pozostali domownicy. W notatkach zachował się tylko program rekolekcji, który ojciec święty trzymał w ręku, słuchając nauk bpa Cortiego. Jan Paweł II pozostał wierny tradycji rekolekcji odprawianych co roku. Te ostatnie dopełnił swoim cierpieniem, poprzez które upodobnił się całkowicie do swojego Mistrza. 


\section{Summary}

\section{The spirituality of bishop Karol Wojtyla - John Paul II in his own notes}

Private notes of Karol Wojtyła - John Paul II just on the moment of death of their author excited big interest between the people. The pope wrote in the testament, his secretary Msgr. Dziwisz has to fire all the documents, he left. Card. Stanisław Dziwisz didn't accomplish the will of pope, because he was convinced, it is very important document, showing the interior life of John Paul II. Recently, the Publishing House Znak printed this Private notes (Krakow 2014) giving to the publicity to know the spiritual life of Karol Wojtyła - John Paul II.

The Private notes are some kind of "diary of the soul" showing deeper life with God of Karol Wojtyła as bishop of Krakow, cardinal and pope. They are giving the possibility to enter in the mystery of the soul of John Paul II, to know his life of prayer, meditation and his relation to God and to Blessed Virgin Mary.

Keywords: private notes, diary of the soul, God and man, interior life, spiritual retreat, day of recollection, breviary

\section{Sylwetka duchowa bpa Karola Wojtyły - Jana Pawła II w osobistych notatkach}

Notatki osobiste Karola Wojtyły - Jana Pawła II już w momencie śmierci wzbudziły duże zainteresowanie. Papież napisał w testamencie, że jego sekretarz prałat Dziwisz powinien spalić wszystkie dokumenty, które zostawił. Kard. Stanisław Dziwisz nie wypełnił woli papieża, ponieważ był przekonany, że jest to zbyt ważny dokument pokazujący życie wewnętrzne Jana Pawła II. Wydawnictwo Znak opublikowało Notatki osobiste (Kraków 2014), dając możliwość poznania życia duchowego Karola Wojtyły - Jana Pawła II.

Notatki osobiste są pewnego rodzaju „dziennikiem duszy”, który odsłania głębsze życie z Bogiem Karola Wojtyły jako biskupa krakowskiego, kardynała i papieża. Notatki pozwalają wniknąć w tajemnicę duszy Jana Pawła II, poznaćjego życie modlitwy, medytację i relację z Bogiem i Matką Bożą.

Słowa kluczowe: notatki osobiste, dziennik duszy, Bóg i człowiek, życie wewnętrzne, rekolekcje, dni skupienia, brewiarz

\section{Bibliografia}

Karol Wojtyła - Jan Paweł II, „Jestem bardzo w rękach Bożych”. Notatki osobiste. 19622003, Kraków 2014.

Jan Paweł II, Dar i Tajemnica, Kraków 1996.

Jan XXIII, Dziennik duszy, Kraków 2014. 
ks. Jan Machniak

Blachnicki F., Międzynarodowa Diakonia Ewangelizacji Światło-Życie, Carlsberg 1983. Granat W., Ku człowiekowi i Bogu w Chrystusie. Zarys dogmatyki katolickiej, t. II, Lublin 1974. Św. Grignon de Montfort L. M., Traktat o prawdziwym nabożeństwie do Najświętszej Maryi Panny, tłum. H. Brownsfordowa, Torun 1996.

Le Guillou M. J., Le Mystère du Père. Foi des Apôtres, Paris 1973. 